\title{
Effect of Soil Texture and Irrigation Water Quality on Peanut Seedlings Infection with Rhizoctonia solani \\ S.M.A. Morsy
}

Plant Pathol. Res. Inst., Agric. Res. Centre, Giza, Egypt.

\begin{abstract}
Qoil texture and quality of irrigation water as factors affecting the Dinfection rates of peanut seedlings with Rhizoctonia solani were studied. Aspergillus niger, Fusarium spp., Rhizoctonia solani and Macrophomina phaseolina were prevalent over the collected rotted samples of peanut roots and fruits in frequencies of (12.0-27.2\%). Results indicated that the highest rate of infection $(62.67 \%)$ occurred in sandy soil, while sandy clay soil gave the lowest rate $(53.33 \%)$. The highest infection rate $(70.67 \%)$ was obtained when irrigation was carried out using ground water. However, irrigation with Nile River gave the least infection rate $(46.67 \%)$. Laboratory experiment using $\mathrm{Ca}^{++}$and $\mathrm{Na}^{+}$ions confirmed the results obtained from the pot experiment irrigated with agricultural waste water which is considered reach in $\mathrm{Ca}^{++}$and $\mathrm{Na}^{+}$ions.
\end{abstract}

Keywords: Damping-off, irrigation water, peanut and soil texture.

Peanut (Arachis hypogea L.) is one of the important annual legume and oil crops in Egypt. Several diseases could be recorded during the growing season, causing great losses in pod yield. Soil and seed borne fungi could attack root, stem and pods causing qualitative and quantitative damages as well as increasing soil infection. Therefore, continuous growing of peanut plants in the same soil subjected the crop to infection with these pathogens under favourable environmental conditions.

Soil texture affected incidence of root and pod rot of peanut caused by several fungi, i.e. Fusarium spp., Macrophomina phaseolina, Rhizoctonia solani and Aspergillus niger as well as affected fungal growth in soil during peanut growing (El-Wakil, 1981and Ismail and Abd El-Momen, 2007). Also, His (1965) found that the finer - textured soils were reported to increase black root rot severity on peanut and soybean (Lockwood et al., 1970), as compared with disease severity on coarsertextured. Soil chemical properties such as high PH (Bateman, 1962) and soil chemical factors related to soil $\mathrm{PH}$, including cation exchange capacity, base saturation and calcium or aluminium ion concentration (Meyer and Shew, 1991) increase disease severity. Recently, root and fruit diseases caused peanut decline (Ismail and Abd El-Momen, 2007). Attempts were made to decrease amount of losses by selecting for resistant cultivars (Jackson, 1962), soil treatment with fungicides (Abdel-Ghany et al., 1973) or applying fertilizers (Abdel-Gallel, 1977).

The analysis of water quality in some irrigation systems found that in $25 \%$ of system, water quality does not meet the requirements, which affected the increase in concentration of salt in the soil above the allowable level, precluding the organic agriculture. Besides the total amount and the content of certain pollutants from the salt, harmful and dangerous substances in the irrigation water often come from 
chemicals which are used in agriculture as pesticides and nutrients, and from the waste waters, or wastes deposited in the watercourses, as well as by the presence of certain microorganisms. Water quality and its hygienic safety exceptionally in vegetable irrigation is extremely important due to increased demand for healthy safe food, and water can transfer harmful microorganisms to the plant products, which may cause diseases to human such as Salmonella sp., Escherichia coli, Cryptosporidium parvum and others (Dragovic et al., 2010).

In Egypt, the main fresh water source is the Nile River from which obtain a fixed amount of water 55.5 milliard $\mathrm{m}^{3} /$ year. It is insufficient according to the increasing population and reclamation of new land demands. Egypt faces increasing competitive demands for that water. Some of the water that is re-used includes municipal waste water which must be applied in accordance with increasingly stringent regulation. Thus it is important for Egypt to turn waste water into an irrigation resource. The majority of municipal waste water estimated as 1.3 billion $\mathrm{m}^{3}$ /annum (Abd El-Naim, 1995). Also, used of agriculture waste water for crop irrigation has been recognized as a potential water resource and as an auxiliary supply for plant nutrients (El-Sayed, 2005).

Rate of infection of peanut stem and root with Rhizoctonia solani was inversely proportional to the seedling age. However, calcium (Ca) content increased as the seedlings become older (El-Samra et al., 1994). Amendment of conductive soil with $\mathrm{CaCO}_{3}$, and/or alfalfa meal reduced damping-off cucumber seedlings caused by Pythium splendens from 78 to 30, 44 and 11\%, respectively, (Kao and Ko, 1986). Moreover, severity of tomato wilt caused by Fusarium oxysporum was increased by deficient calcium $(\mathrm{Ca})$ nutrition after infection and decreased when the deficiency occurred before infection (Malcolm, 1965). The objective of the present study was designed to test the effect of soil texture and irrigation water quality on infection of peanut seedlings with damping-off disease caused by Rhizoctonia solani.

\section{M at e rials and Methods}

Isolation and identification of peanut root and pods rot fungi:

Survey of peanut root and pod rot diseases was carried out during the period from 2009 to 2010 growing seasons in different localities of South Tahrir, Behera Governorates. Collected samples of diseased peanut root and pods after harvest were washed with tap water. Small pieces of the diseased parts, were surface sterilized by immersing in $3 \%$ sodium hypochlorite solution for three minutes, rinsed several times in sterilized distilled water and dried between two sterilized filter papers, then placed on PDA medium in Petri-dishes and incubated at $22 \pm 1^{\circ} \mathrm{C}$ for 3 to 7 days. Hyphal tip or single spore of each the developing fungi was transferred to PDA medium. Inoculum of each purified culture was transferred into PDA slant and incubated at $25^{\circ} \mathrm{C}$. The developed fungal growth was sub cultured and identified according to Hildeband (1938), Gilman, (1957) and Booth (1971). Stock cultures were maintained on PDA slant and kept in a refrigerator at $5^{\circ} \mathrm{C}$ for further studies.

Egypt. J. Phytopathol., Vol. 41, No. 1 (2013) 
Types of soil:

Soil samples were collected at surface layer $(0-20 \mathrm{~cm})$ from different areas located in Behera Governorate. The chemical analysis and some characters of soil used in experiments were carried out at the Unit of Soil, Water and Environment Research Institute, Agriculture Research Centre, Giza, Egypt. The characteristics of the analyzed soils used are shown in Table (1).

Table 1. Some characteristics of soil types used in the experiment

\begin{tabular}{|l|c|c|c|}
\hline \multicolumn{1}{|c|}{ Parameter } & $\begin{array}{c}\text { Sandy soil } \\
\text { No.1 }\end{array}$ & Sandy clay soil & $\begin{array}{c}\text { Sandy soil } \\
\text { No.2 }\end{array}$ \\
\hline Particle- size distribution: & & & \\
Sand\% & 98.10 & 82.85 & 98.10 \\
Silt \% & 1.20 & 5.65 & 1.4 \\
Clay \% & 0.7 & 11.50 & 0.5 \\
Textural class & Sandy & Sandy clay & Sandy \\
Saturation percentage \% & 20.0 & 23.0 & 20.0 \\
Field capacity \% & 13.0 & 17.3 & 9.4 \\
Organic matter \% & 0.04 & 0.09 & 0.05 \\
pH (1:1) & 7.6 & 8.1 & 7.8 \\
EC (1:1, soil : water) dsm ${ }^{-1}$ & 1.29 & 1.85 & 1.37 \\
\hline Soluble cations, meq/l : & & & 3.15 \\
Calcium & 2.99 & 5.16 & 2.05 \\
Magnesium & 1.54 & 3.78 & 8.37 \\
Sodium & 8.22 & 9.39 & 0.2 \\
Potassium & 0.25 & 0.22 & \\
& & & 8.66 \\
\hline Soluble anions, meq/l : & & 8.48 & 29.22 \\
Chloride & 7.72 & 59.48 & 1.85 \\
Available- k, mg/kg soil & 23.82 & 4.84 & 0.05 \\
Available- P, mg/kg soil & 17.34 & 0.02 & \\
Total N, \% & 0.07 & & \\
\hline
\end{tabular}

Types of irrigation water:

Three samples of irrigation water with different qualities were used in this study, Nile River water (Nasser Project), Agricultural waste water and ground water were collected from South Tahrir, Behera Governorate. Water samples were analyzed at Unit of Soil, Water and Environment Research Institute, Agriculture Research Centre, Giza, Egypt. Table (2) show the chemical composition of the different types of irrigation water used.

Peanut seeds preparation:

Certified peanut seeds (cv. Giza 6) obtained from the Agricultural Research Centre (ARC), Giza, Egypt, were sterilized by immersing in $3 \%$ sodium hypochlorite solution for 2 min. and rinsed several times in sterilized water, then dried with sterilized filter paper. 
Table 2. Chemical composition of the three types of irrigation water

\begin{tabular}{|l|c|c|c|}
\hline \multicolumn{1}{|c|}{ Parameter } & $\begin{array}{c}\text { Nile River } \\
\text { water (NR) }\end{array}$ & $\begin{array}{c}\text { Agricultural waste } \\
\text { water (AWW) }\end{array}$ & $\begin{array}{c}\text { Ground water } \\
(\mathrm{GW})\end{array}$ \\
\hline PH & 7.35 & 7.50 & 7.62 \\
\hline EC,dSm & -1 & 0.93 & 3.24 \\
\hline Soluble cations, meq/l : & 0.37 & 3.53 & 5.00 \\
Calcium & 1.46 & 1.70 & 5.50 \\
Magnesium & 1.33 & 3.25 & 20.30 \\
Sodium & 0.84 & 0.90 & 0.27 \\
Potassium & 0.09 & & \\
\hline Soluble Anions, meq/l : & & 3.25 & 6.00 \\
Carbonates bicarbonates & 1.89 & 1.17 & 22.50 \\
Chloride & 0.74 & 4.96 & 2.57 \\
Sulphate & 1.09 & & \\
\hline
\end{tabular}

\section{Greenhouse experiment:}

Inoculation tests were carried out in plastic pots (20-cm-diam.). Plastic pots were sterilized by submerging in 5\% formaldehyde solution for a few hours and left for ventilation. Soil was autoclaved at pressure of $1.5 \mathrm{~kg} / \mathrm{cm}^{2}$ for $90 \mathrm{~min}$. and then left to be ventilated for 7 days before adding the inoculum. Inocula were prepared by growing the tested isolate of Rhizoctonia solani on Potato Dextrose broth medium in $250 \mathrm{ml}$ conical flasks, each containing $50 \mathrm{ml}$ of the medium. Inoculated flasks were incubated at $27^{\circ} \mathrm{C}$ for one week, after which fungal mats were collected, blended with tap water and used as inocula at the rate of $2.5 \mathrm{~g} / \mathrm{kg}$ of autoclaved soils. Surface sterilized seeds were planted at the rate of 4 seeds/pot and kept in the greenhouse.

Pot experiment was a factorial experiment in randomized complete block design with four replication for each treatment. The factors were soil texture as main treatment and type of irrigation water as sub main treatment. Percentages of pre- and post-emergence damping-off were recorded after 15 and 40 days of sowing for each treatment. After 45 days, seedlings of each pot were picked up and washed with tap water. They were left to air drying and then dried in oven at $65^{\circ} \mathrm{C}$ for $48 \mathrm{hrs}$ or up to constant weight. The dried material was grounded in Wiley mill and stored for analysis. Samples of seedlings powder were analysis at Unit of Soil, water and Environment Research Institutes, Agriculture Research Centre, Giza, Egypt.

The collected data were subjected to analysis of variance (ANOVA) for effect of soil textures and types of irrigation water. The statistical analysis was conducted according to the methods of (Steel and Torrie, 1982).

Laboratory experiment:

In order to check the effect of some ions concentration on the growth of $R$. solani, calcium and sodium ions at the rate of 50,100, 200, 300, 500 and 600ppm were tested. The isolate of $R$. solani was grown in $250 \mathrm{ml} /$ flask containing $50 \mathrm{ml}$ PD broth supplemented with the proposed calcium and sodium ions concentrations and incubated at $28^{\circ} \mathrm{C}$ for two weeks. The mycelial mats were then harvested, filtered and dried between two filter papers and then weighted as a fresh weight, 
then dried in oven for $48 \mathrm{hrs}$ at $65^{\circ} \mathrm{C}$ or up to constant weight and weighed. All treatments were repeated five times in completely randomized design. Linear growth of each treatment was recorded as $\mathrm{mm}$ after $24 \mathrm{hrs}$ at $25^{\circ} \mathrm{C}$.

\section{Results and Discussion}

Fungi associated with root and fruits rot of peanut:

Different fungi were isolated from root and stem of peanut plants showing root rot, damping-off and fruits rot symptoms collected from newly reclaimed lands in Behera Governorate (Table 3). Aspergillus niger, Fusarium spp., Rhizoctonia solani and Macrophomina phaseolina were prevalent over the collected samples and recorded in frequencies of $(25.3 \& 27.2 \%),(20.3 \& 18.2 \%),(14.0 \& 13.8 \%)$ and $(12.3 \& 12.0 \%)$ for root and fruits, respectively. Sclerotium rolfsii, Rhizopus stolonifer, Aspergillus flavus, Pythium debaryanum and Mucor spp. were also recovered but at lower frequencies of $(4.5 \& 8.8 \%),(4.0 \& 3.0 \%),(3.5 \& 2.4 \%)$, $(3.0 \& 2.8 \%)$ and $(2.5 \& 2.2 \%)$ for root and fruits, respectively. These results are in harmony with those of many researchers (Garren, 1970; Atta-Alla et al., 2004 and Ismail and Abd El-Momen, 2007).

Table 3. Frequency of isolated fungi from peanut samples showing root-rot, damping-off and fruits rot symptoms ${ }^{1}$

\begin{tabular}{|c|c|c|}
\hline \multirow{2}{*}{ Fungus } & \multicolumn{2}{|c|}{ Fungal frequency $(\%)$ on plant part } \\
\hline & Root and stem ${ }^{2}$ & Fruits $^{3}$ \\
\hline Aspergillus niger & 25.3 & 27.2 \\
\hline Fusarium spp. & 20.3 & 18.2 \\
\hline Rhizoctonia soloni & 14.0 & 13.8 \\
\hline Macrophomina phaseolina & 12.3 & 12.0 \\
\hline Sclerotium rolfsii & 4.5 & 8.8 \\
\hline Rhizopus stolonifer & 4.0 & 3.0 \\
\hline Aspergillus flavus & 3.5 & 2.4 \\
\hline Pythium debaryanum & 3.0 & 2.8 \\
\hline Mucor spp. & 2.5 & 2.2 \\
\hline Other fungi & 10.8 & 9.6 \\
\hline
\end{tabular}

${ }^{1}$ Samples collected from different localities at Behera Governorate during 2009-2010 summer seasons

${ }^{2}$ Total samples $=400$

${ }^{3}$ Total samples $=500$

Greenhouse experiment:

Results presented in Table (4) indicate that the percentage of pre- and postemergence damping-off of peanut plants grown in varied conditions of soil texture and quality of irrigation water. 
a) Effect of soil texture:

Results in Table (4) show that tested Rhizoctonia solani isolate could incite the pre-and post- emergence damping-off in different soil textures in varying degrees. The highest value of peanut seedling infection occurred in sandy soil (Nos. 1\&2). On the other hand, the lowest infection occurred in sandy clay soil. The mean percentages of pre-emergence damping-off reached 32, 24 and $28 \%$ for sandy soil (No.1), sandy clay and sandy soil (No.2), respectively.

The corresponding values for post-emergence damping-off were 30.67, 29.33 and $32.0 \%$, respectively, meanwhile the total infection reached $62.67,53.33$ and $60 \%$, respectively. It is clear that the total pre- and post-emergence damping-off was lowest in sandy clay soil than the other tested soils.

Table 4. Percentages of pre- and post- emergence damping-off and total infection of peanut seedlings with $R$. solani in response to soil texture and irrigations water quality

\begin{tabular}{|l|l|c|c|c|}
\hline \multicolumn{1}{|c|}{ Soil texture } & \multicolumn{1}{|c|}{$\begin{array}{c}\text { Irrigation water } \\
\text { quality }\end{array}$} & $\begin{array}{c}\text { Pre- } \\
\text { emergence }\end{array}$ & $\begin{array}{c}\text { Post- } \\
\text { emergence }\end{array}$ & $\begin{array}{c}\text { Total } \\
\text { infection }\end{array}$ \\
\hline \multirow{3}{*}{ Sandy soil (1) } & Nile River & 28 & 20 & 48 \\
\cline { 2 - 5 } & Agric. waste water & 32 & 28 & 60 \\
\cline { 2 - 5 } & Ground water & 36 & 44 & 80 \\
\hline \multirow{3}{*}{ Sandy clay } & Nile River & 20 & 24 & 44 \\
\cline { 2 - 5 } & Agric. waste water & 28 & 28 & 56 \\
\cline { 2 - 5 } & Ground water & 24 & 36 & 60 \\
\hline \multirow{4}{*}{ Sandy soil (2) } & Nile River & 24 & 24 & 48 \\
\cline { 2 - 5 } & Agric. waste water & 28 & 32 & 60 \\
\cline { 2 - 5 } & Ground water & 32 & 40 & 72 \\
\hline Mean effect of soil texture: & 32 & 30.67 & 62.67 \\
Sandy soil (1) & & 24 & 29.33 & 53.33 \\
Sandy clay & 28 & 32.00 & 60.00 \\
\hline Sandy soil (2) & n.s. & n.s. & \\
\hline \multicolumn{2}{|l}{ L.S.D 0.05 } & 24.00 & 22.67 & 46.67 \\
\hline Mean effect of irrigation water quality: & 29.33 & 29.33 & 58.66 \\
Nile River & 30.67 & 40.00 & 70.67 \\
\hline Agric. waste water \\
Ground water & n.s. & 5.02 & \\
\hline \multicolumn{2}{|l|}{ L.S.D. 0.05 } & &
\end{tabular}

Available reports on the relation between soil type and diseases development are, somewhat, contradictory. Macrophomina phaseolina infection of crop plants are more sever on sandy soils than on heavy soils. His (1965) stated that charcoal rot of sorghum was more severe in sandy than clay soils. He attributed that as sandy soils have less water holding capacity and also become dry more quickly than the day soils. These soils are more variable in temperatures and generally warmer than clay soils during day- time. Also, these results are in agreement with those of El-Wakil (1981), El-Farnawany and Abdel-Nasser (1995). Also, Mahmoud et al. (2006) found 
that under greenhouse and field conditions all tested peanut cultivars varied in their susceptibility to infection by damping-off and peanut root rots. They added that cvs. Ismailia 1 and R 92, were the most resistant against infection by damping-off and peanut root-rot diseases and gave the highest percentage of survived plants, while cvs. Giza 5, Giza 4 and Georgia were the highly susceptible cultivars to the infection by damping-off and peanut root-rot.

b) Effect of water quality:

Results presented in Table (4) show that $R$. solani could cause pre-, and postemergence damping-off infection to peanut seedlings at the different types of irrigation water in varied degrees. The highest percentage of pre- and postemergence damping-off were observed in the case of using ground water $(\mathrm{GW})$, but the lowest values were observed with Nile River (NR), the mean values of preemergence damping-off reached 24, 29.33 and 30.67\% for NR, AWW and GW, respectively. Meanwhile, the corresponding values for post- emergence damping-off of peanut seedlings were $22.67,29.33$ and $40.0 \%$ and for the total infection were $46.67,58.66$, and $70.67 \%$ for RN, AWW and GW, respectively. Generally, the total infection percentage of peanut seedlings damping-off caused by $R$. solani showed low records in case of sandy clay soil irrigated with the agricultural waste water. The low infection records of $R$. solani in the case of using (R.N.) followed by $(\mathrm{AWN})$ may be due to the higher salinity of water $\left(\mathrm{EC}=0.37\right.$ and $.93 \mathrm{dSm}^{-1}$, respectively), which increase the osmotic pressure of media and consequently causes the plasmolysis of fungal cells (El-Samra et al., 1994). Moreover, the increase of calcium or concentration $\left(3.53 \mathrm{meq} / \mathrm{l}^{-1}\right)$ leads to significant decrease in disease severity (El-Samra et al., 1994). Also, the low percentage of infection was observed in case of sandy clay soil it may be due to the higher percentage of $\mathrm{CaCO}_{3}$ (3.25 meq/ $\left./ \mathrm{l}^{-1}\right)$ as stated by Kao and Ko (1986).

Data in Table (5) show the recorded fresh and dry weight and elements composition of shoot of peanuts plants as affected by soil texture and irrigation quality. It was clear that the highest fresh weight of shoots was recorded in the case of sandy clay soil $4.37 \mathrm{~g} /$ plant, followed by sandy soil (No.1) $4.12 \mathrm{~g} / \mathrm{plant}$. However, the lowest weight of fresh shoot obtained when use sandy soil No.2 (3.73g/plant). Similar results were obtained in case of dry weight whereas $0.66,0.91$ and 0.60 $\mathrm{gm} /$ plant for sandy soil No.1, sandy clay soil and sandy soil No.2 were recorded, respectively. On the other hand, the highest weight of fresh and dry weight were observed in the case of using River Nil 4.25 and $0.85 \mathrm{gm} / \mathrm{plant}$, but the lowest values were observed as 3.8 and $0.63 \mathrm{gm} / \mathrm{plant}$, in case of using ground water, respectively. Data in Table (5) also, indicated the percentage of elements content in peanut seedlings. The highest values of nitrogen, phosphorus and calcium $(2.85,0.564$ and $0.59 \%$ ) were obtained when peanut plants sown in sandy soil No.2 while, the lower values of $\mathrm{N}$ and $\mathrm{Na}(2.76 \%$ and $0.60 \%)$ were found in sandy soil No.1. The irrigation water quality seems to affect the element content in seedling peanut. It is observed that agriculture waste water irrigation increased total content in $\mathrm{N}, \mathrm{Ca}$ and $\mathrm{Na}(2.87,0.57$ and $0.88 \%)$ while, ground water gave highest value $(0.569 \%)$ of $\mathrm{P}$ also, the highest value of K $1.78 \%$ was obtained when Nile River is used as irrigation water. Calcium affects the susceptibility of pectic substances to enzymatic 
Table 5. Plant growth parameters and elemental composition of peanut seedlings infected by $R$. solani as affected by soil texture and irrigation water quality

\begin{tabular}{|c|c|c|c|c|c|c|c|c|}
\hline \multirow{2}{*}{ Soil texture } & \multirow{2}{*}{$\begin{array}{c}\text { Irrigation } \\
\text { water quality }\end{array}$} & \multirow{2}{*}{$\begin{array}{c}\text { Fresh } \\
\text { weight } \\
(\mathrm{g})\end{array}$} & \multirow{2}{*}{$\begin{array}{c}\text { Dry } \\
\text { weight } \\
(\mathrm{g})\end{array}$} & \multicolumn{5}{|c|}{ Elemental composition (\%) } \\
\hline & & & & $\mathrm{N}$ & $\mathrm{P}$ & $\mathrm{K}$ & $\mathrm{Ca}$ & $\mathrm{Na}$ \\
\hline \multirow{3}{*}{$\begin{array}{l}\text { Sandy soil } \\
\text { (No.1) }\end{array}$} & Nile River & 4.37 & 0.82 & 2.99 & 0.468 & 1.71 & 0.54 & 0.50 \\
\hline & Agric. waste water & 4.11 & 0.67 & 2.68 & 0.576 & 1.49 & 0.51 & 0.79 \\
\hline & Ground water & 3.93 & 0.51 & 2.62 & 0.584 & 2.13 & 0.51 & 0.52 \\
\hline \multirow{3}{*}{ Sandy clay soil } & Nile River & 5.08 & 1.13 & 2.27 & 0.474 & 1.40 & 0.47 & 0.62 \\
\hline & Agric. waste water & 4.14 & 0.83 & 3.24 & 0.472 & 1.53 & 0.57 & 0.90 \\
\hline & Ground water & 3.95 & 0.80 & 2.92 & 0.471 & 1.36 & 0.55 & 1.03 \\
\hline \multirow{3}{*}{$\begin{array}{l}\text { Sandy soil } \\
\text { (No. 2) }\end{array}$} & Nile River & 3.80 & 0.62 & 2.82 & 0.573 & 1.44 & 0.49 & 0.52 \\
\hline & Agric. waste water & 3.70 & 0.60 & 2.68 & 0.466 & 0.45 & 0.64 & 0.96 \\
\hline & Ground water & 3.70 & 0.58 & 3.04 & 0.653 & 1.32 & 0.63 & 0.57 \\
\hline \multicolumn{2}{|c|}{ Mean effect of soil texture: } & & & & & & & \\
\hline \multicolumn{2}{|c|}{ Sandy soil (No .1) } & 4.12 & 0.66 & 2.76 & 0.543 & 1.52 & 0.52 & 0.60 \\
\hline \multicolumn{2}{|l|}{ Sandy clay soil } & 4.37 & 0.91 & 2.81 & 0.472 & 1.49 & 0.50 & 0.85 \\
\hline \multicolumn{2}{|c|}{ Sandy soil (No.2) } & 3.73 & 0.60 & 2.85 & 0.564 & 1.40 & 0.59 & 0.68 \\
\hline \multicolumn{2}{|c|}{ L.S.D. 0.05} & 0.81 & 0.017 & n.s. & 0.07 & 0.28 & 0.098 & 0.11 \\
\hline \multirow{2}{*}{\multicolumn{2}{|c|}{$\begin{array}{l}\text { Mean effect of irrigation water: } \\
\text { Nile River }\end{array}$}} & & & & & & & \\
\hline & & 4.25 & 0.85 & 2.69 & 0.505 & 1.78 & 0.50 & 0.54 \\
\hline \multicolumn{2}{|c|}{ Agric. waste water } & 4.00 & 0.75 & 2.87 & 0.505 & 1.43 & 0.57 & 0.88 \\
\hline \multicolumn{2}{|l|}{ Ground water } & 3.80 & 0.63 & 2.86 & 0.569 & 1.60 & 0.56 & 0.71 \\
\hline \multicolumn{2}{|c|}{ L.S.D. 0.05} & 0.59 & 0.02 & n.s. & 0.07 & n.s. & 0.08 & 0.11 \\
\hline
\end{tabular}

hydrolysis in which $\mathrm{Ca}$ inhibit the fungal polygalacturonase and had the effect on the substrate and not on the enzyme itself (McClendon and Somers, 1960). Also, various researchers have shown the importance of calcium rate and timing with relationship to yield of both runner and Virginia type peanut (Gricher et al., 2004 and Wiatrak et al., 2006). Furthermore, Garren (1964) reported that high rates of calcium added to soil in the form of gypsum $\left(\mathrm{CaSO}_{4} \cdot 2 \mathrm{H}_{2} \mathrm{O}\right)$ up to $8.960 \mathrm{~kg} / \mathrm{ha}$ effectively reduced pod rot. Further study of Hailock and Garren (1968) suggested that the calcium content of peanut pods was important in suppression of pod rot caused by $P$. myriotylum. They added that pods containing $>0.20 \%$ calcium had less disease than those containing $<0.15 \%$ of calcium. Sodium ion $\left(\mathrm{Na}^{+}\right)$may play a role in peanut seedling resistance to damping- off, it may be due to the toxic effect of $\mathrm{Na}^{+}$ion on the fungal cells (El-Farnawany and Abdel-Nasser, 1995). This may be responsible for plant resistance against damping-off caused by $R$. solani in which agricultural waste water-treated seedlings had less infection Table (5). Porter and Adamsen (1993) found that concentration of sodium in groundnut tissues and soil, as well as the severity and incidence of early leaf spot, were influenced by water quality and method of irrigation. They added that mean $\mathrm{Na}$ levels were always higher in tissues of plants receiving sprinkle - applied deep - well water containing an average $\mathrm{Na}$ concentration of $220 \mathrm{mg} /$ litre. Also, soil $\mathrm{Na}$ was higher in plots receiving sodic water and mean percentages of diseased leaflets, defoliation and number of lesions/leaflet 25, 60 and $35 \%$ greater, respectively, in plant receiving sodic irrigation water than in plants receiving non-sodic water. 


\section{Laboratory experiment:}

The effect of different concentrations of $\mathrm{Ca}^{++}$and $\mathrm{Na}^{+}$ions on tested $R$. solani linear growth was studied on PDA medium, meanwhile the fresh and dry weight of fungus was determined on potato dextrose liquid medium.

From the results presented in Table (6), it could be observed that $\mathrm{Ca}^{++}$and $\mathrm{Na}^{+}$ ions stimulate the linear growth of $R$. solani grown on PDA media. Results proved that the low concentration of $\mathrm{Ca}^{++}$and $\mathrm{Na}^{+}$ions stimulated the growth of $R$. solani up to $50 \mathrm{ppm}$. However, the least rates of linear growth, fresh and dry weight of mycelium mat could be detected when concentration of $600 \mathrm{ppm}$ for both $\mathrm{Ca}^{++}$and $\mathrm{Na}^{+}$ions was applied.

Table 6. Linear growth and fresh and dry weights of mycelium mate of Rhizoctonia solani grown on media supplemented with different concentrations of sodium and calcium ions

\begin{tabular}{|c|c|c|c|c|c|c|}
\hline \multirow{2}{*}{$\begin{array}{c}\text { Concentration } \\
(\mathrm{ppm})\end{array}$} & \multicolumn{3}{|c|}{ Sodium ion } & \multicolumn{3}{c|}{ Calcium ion } \\
\cline { 2 - 7 } & $\begin{array}{c}\text { Linear growth* } \\
(\mathrm{cm})\end{array}$ & $\begin{array}{c}\text { Fresh } \\
\text { weight } \\
(\mathrm{g})\end{array}$ & $\begin{array}{c}\text { Dry } \\
\text { weight } \\
(\mathrm{g})\end{array}$ & $\begin{array}{c}\text { Linear growth } \\
(\mathrm{cm})\end{array}$ & $\begin{array}{c}\text { Fresh } \\
\text { weight } \\
(\mathrm{g})\end{array}$ & $\begin{array}{c}\text { Dry } \\
\text { weight } \\
(\mathrm{g})\end{array}$ \\
\hline Control & 3.25 & 1.98 & 0.35 & 3.30 & 2.51 & 0.35 \\
\hline 50 & 3.37 & 3.07 & 0.27 & 3.57 & 3.21 & 0.34 \\
\hline 100 & 3.56 & 3.18 & 0.31 & 4.23 & 3.31 & 0.44 \\
\hline 200 & 3.3 & 3.29 & 0.35 & 4.53 & 2.89 & 0.38 \\
\hline 300 & 3.24 & 3.38 & 0.36 & 3.95 & 2.59 & 0.32 \\
\hline 500 & 2.75 & 3.48 & 0.34 & 3.67 & 2.07 & 0.28 \\
\hline 600 & 2.3 & 2.22 & 0.25 & 3.34 & 2.03 & 0.26 \\
\hline L.S.D 0.05\% & 0.45 & 0.47 & 0.02 & 0.41 & 0.49 & 0.04 \\
\hline
\end{tabular}

* Data were recorded 24 hours after inoculation of tested media.

\section{R e f e r e n c e s}

Abdel-Gallel, A.A. 1977. Studies on root rot disease of peanut in A.R.E. and its control. M.Sc. Thesis, Fac. Agric., Zagazig Univ. 107 pp.

Abdel-Ghany, A.K.; Seoud, M.B.; Abdel-Aziz, M.F.; Mahmoud, B.K.; EL-Alfy, Kawthar A. and Abd-EL- Gawad, M. 1973. Peg and rot disease of peanut and its control. Agric. Res. Rev. Egypt, 51: 129-138.

Abd El-Naim, E.M. 1995. Re-use of treated waste water in agriculture. Proc. of $2^{\text {nd }}$ Conf. on Farm Irrigation and Agroclimatology. Organized by soils and water Res. Inst., Agric. Res. Centre, Ministry of Agric. and land Reclamation.

Atta-Alla, S.I.; El-Samra, I.A.; El-Korany, A.E.; El-Sheikh, M.A. and El-Nawam, M.F. 2004. Management of the root rot of peanut in the newly reclaimed land in Behera Governorate, Egypt. J. Agric. Environ. Sci., Alex. Univ., 3 (1) 9-23.

Bateman, D.F. 1962. Relation of soil $\mathrm{pH}$ to development of poinsettia root rots. Phytopathology, 52: 559-566. 
Booth, C. 1971. The Genus Fusarium. Commonwealth Mycological Institute, Kew Surrey, England. 237pp.

Dragovic, S.; Radojevic, V.; Cicmil, M. and Uscumlic, M. 2010.Importance of the water quality for irrigation in organic food production in view of chemical and microbiological safety. http //docs. google.com

El-Farnawany, M.A. and Abdel-Nasser, G. 1995. Effect of soil texture and irrigation water quality on infection of bean seedlings (Phaseolus vulgaris L.) with Rhizoctonia solani. Alex. Sci. Exch., 16 (4): 483-494.

El-Samra, I.A.; Noaman, K.A.; Fayed M.A. and El-Farnawany, M.A. 1994. Studies on hyphal anastomosis and pathogenicity of some Rhizoctonia solani Kuhn isolates recovered from different host plants. J. Agric. Sci., Mansoura Univ., 18 (10): 2947-2959.

El-Sayed, N.A.A. 2005.The impact of irrigation with treated wastewater after effluent on soil Bio-physicochemical properties fodder trees grown on calcareous soil. Ph.D. Thesis, Fac. of. Agric., Tanta, Univ., Tanta, Egypt.

El-Wakil, A.A. 1981. Studies on the genus Sclerotium its taxonomy, importance and factors affecting its spread on peanut in Egypt. Ph.D. Thesis, Fac. of Agric., Zagazig Univ. 172pp.

Garren, K.H. 1964. Land plaster and soil rot of peanut pods in Virginia. Plant Dis. Reptr., 48: 349-352.

Garren, K.H. 1970. Rhizoctonia solani versus Pythium myriotylum as pathogens of peanut pod breakdown. Plant Dis. Reptr., 54:542-543.

Gilman, J.C. 1957. A Manual of Soil Fungi. Iowa State College Press, U.S.A., pp. 450 .

Gricher, W.J.; Besler, B.A. and Melouk, H.A. 2004. Peanut (Arachis hypogaea) response to agricultural and power plant by product calcium. Peanut Sci., 31(2): 95-101.

Hailock, D.L. and Garren, K.H. 1968. Pod break down yield and grad of Virginia type peanuts as affected by Ca, Mg and K sulfates. Agron. J., 60: 253-257.

Hildeband, E.M. 1938. Techniques for the isolation of single microoganisms. Botany, 4: 628- 658.

His, D.C.H. 1965. Black Hull Disease of Valencia Peanuts. N.M. State Univ. Rep. 110pp.

Ismail, F.M. and Abd El-Momen, S.M. 2007. Effect of some soil amendments on yield and disease incidence in peanut (Arachis hypogea L.). Egypt. J. Agric. Res., 85 (2): 379-399.

Jackson, C.R. 1962. Aspergillus crown rot in Georgia. Pl. Dis. Reptr., 46: 888-892.

Egypt. J. Phytopathol., Vol. 41, No. 1 (2013) 
Kao, C.W. and Ko, W.H. 1986. The role of calcium and microorganisms in suppression of cucumber damping-off caused by Pythium splendens in Hawaiian soil. Phytopathology, 76: 221-224. .

Lockwood, J.L.; Yoder, D.L. and Smith, N.A. 1970. Thielaviopsis basicola root rot of soybean in Michigan. Plant Dis. Reptr., 54: 845-850.

Mahmoud , E.Y.; Draz, Eetmad E.I. and Abol-Ela, M.F. 2006. Evaluation of some peanut cultivars for the susceptibility of infection by damping-off, root and pod rot diseases and occurrence of aflatoxigenic fungi. J. Agric. Sci. Mansoura Univ., 31(12): 7589-7604.

Malcolm, E.C. 1965. Influence of calcium nutrition on Fusarium wilt of tomato and polygalacturonase activity. Phytopathology, 55: 222 -224.

McClendon, J.H. and Somers, G.F. 1960. The enzymatic maceration of plant tissues observations using a new method of measurement. Amer. J. Bot., 47: 1-7.

Meyer, J.R. and Shew, H.D. 1991. Soils suppressive to black root rot of burley tobacco caused by Thielaviopsis basicola. Phytopathology, 81: 946-954.

Porter, D.M. and Adamsen, F.J. 1993. Effect of sodic water and irrigation on sodium levels and the development of early leaf spot in peanuts. Plant Dis., 77 (5): 480-483.

Steel, R.G. and Torrie, J. H. 1982. Principles and procedures of statics. McGrawHill Book Company, NY, USA.

Wiatrak , P.J.; Wright, D.L.; Marois, J.J. and Wilson, D. 2006. Influence of gypsum application on peanut yield and quality. Online, Grope Management, dot: 10.1094/CM.2006-0223-01-R.S.

(Received 15/10/2012;

in revised form 19/11/2012)

Egypt. J. Phytopathol., Vol. 41, No. 1 (2013) 


\section{تأثير قوام التربه ونوعية مياه الرى على إصابة

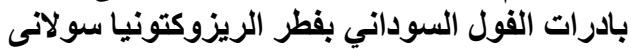 صابر محمد على مرسى الفود معهد بحوث أمر اض النباتات ــ مركز البحوث الزر اعية ـ الجيزةـ}

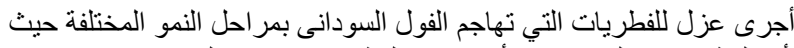

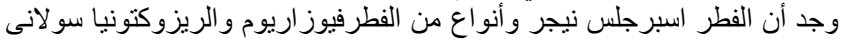

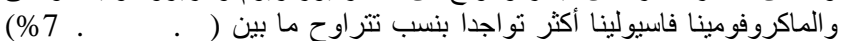

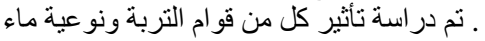

الرى على اصابة بادرات الفول السودانى بالفطر ريزوكتونيا سولانى ، الترن ، حيث

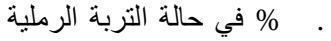

بينما كانت اقلها فى نسبة الاصابة

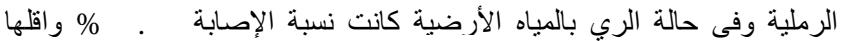

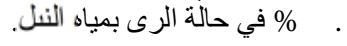

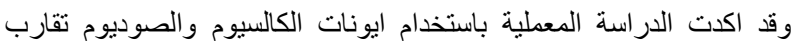

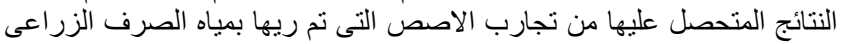

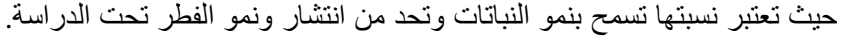

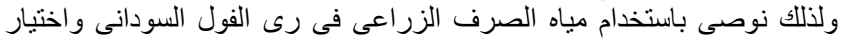

